igneous rocks of the area are essentially fissure accumulations of lava, continuous with a rim of marginal sills which had found entry amidst the indipping strata of the surrounding Mid-Triassic flexures.

The leading east-rest eruptire fissure of Bufaure, and a parallel fissure at Rodella Hill on the north, may be traced continuousle eastward to the Fedaja and Buchenstein district, and westward through the slopes of Duron Valley to Seiser Alpe. Both on the north and south margins--for example, at Plattkofl and Sasso Pitschi on the north margin, and at Mairin Wand, Udai, Molignon, Rosszähne, and Schlern on the south margin-there is a rupid passage of all or part of the lavas and tuffs of the fissure facies into calcareo-dolomitic rocks of the same age. The still higher horizons of Schlern Dolomite can in some places, such as Pordoi in Sella Massive, be seen to give place to the "Schlern Plateau facies" of Raibl strata, which locally includes thin lavas, or to pass insensibly upward into well-stratified Raibl horizons of dolomite.

Round the west of the Seiser Alpe area, the Bufaure and Rodella east-west eruptire fissures become continuous with the leading eastwest eruptire fissure which in Mid-'l'riassic time was actice along the north of Seiser Alpe, the Langkof and Sella Mountains, and the St. Cassian-in-Enneberg meadowland. This fissure is the "Pitzculatsch fault" in ms Grüden Pass section (Q.J.G.S. 1899, rol. lv, pp. 567569), and is that against which, subsequently to Mid-Triassic eras, the "Montesora segment" was pinched up between the fissure facies and the dolomitic.

The general conclusions which I draw from these observations will be fully set forth in the published paper, which will be accompanied by an illustrative series of parallel sections.

\title{
NOTICES OF MFMIOIES.
}

Britrsh Assoctation for the Adpaxcenext of Schence: Serentyserexti dxvoal Gexeral Meeting held at Leicester, A UG UST 1st, 1907.

I.-Address to the Geological section. By Professor J. W. Gregorr, D.Sc., F.R.S., President of the Section.

I. The Geological Society of London.-1907! 'This is the centenary year of the Geological Society of London; next month the British geologists will celebrate the erent, and their pleasure will be enhanced by the sympathetic presence of a distinguished company of foreign geologists.

With a just feeling of satisfaction may we celebrate this event; for to the Geological Society of London is due the conrersion of geology from a fanciful speculation to an ordered science. Yet so quietly has this society done its work that the debt due to it is inadequately realised. When we consider what the world owes to geology in respect of its economic guidance, the intellectual stimulus of its conceptions, the reverence it inspires for the venerable and majestic 
universe, its liberating influence from dogma, we may rightly regard the work of the Geological Society as one of the most valuable British contributions to intellectual progress during the nineteenth century.

A hundred years ago the spirit of the eighteenth century still controlled much of the then orthodox geology. Jameson's "Elements of Geognosy," of which the preface is dated January 15th, 1808, taught, as the certain conclusions of geology, doctrines that had been reached by applying prejudiced speculation to imaginary facts. It was a manual of pure, a priori, Wernerian geology. The author claimed that to Werner "we owe almost everything that is truly raluable in this important branch of knowledge"; and that it was Werner "who had discovered the general structure of the crust of the globe and pointed out the true mode of examining and ascertaining those great relations which it is one of the principal objects of geognosy to investigate."

But Jameson's book was the death-song of Wernerian geology in British science. A new geology was developing, and the Geological Society of London ushered in its birth. No more should observations be made through the distorting medium of preconceived fancies! No more should geology be inspired by that heedless spirit which cares not to distinguish between fancy and fact! With youthful vigour the new geology would have nothing to do with the search for cosmogonies and such like fancy foods; and the Geological Society of London should be nourished on unadulterated facts.

The time was ripe for the change. No less a person than Goethe, once an enthusiastic votary of geology, was now, in his plas of "Faust," holding up its teachers to ridicule. The theories "evolved from the inner consciousness " of Gontinental Neptunists and Plutonists were to Goethe excellent subjects for caricature. It was then the Englishman, Greenough, founded a society to turn geology from the pursuit of fleeting fancies and lead her to the study of sober but enduring facts. The members of this society were to abandon the quest of scientific chimæras; they were to leave to later generations the attempt to solve the universe as a whole.

The Geological Society has owed its influence to its bold, original purpose. It was not founded as a drifting social union of men with a common interest in a single science. Its object was to apply to geolog $y$ one particular mode of research. It alopted as its motto this fine passage from Bacon:-

"If any man makes it his delight and care-not so much to cling to and use past discoveries, as to penetrate to what is beyond them-not to conquer Nature by talk, but by toil-in short, not to hare elegant and plausible theories, but to gain sure and demonstrable knowledge; let such men (if it shall seem to them right), as true children of knowledge, unite themselves with us."

The methods of the society were as practical as its ideals. London, with characteristic unconventionality and originality, has used its scientific societies as its university for post-graduate teaching. Informally the Geological Society enrolled every British master of geology on its staff of unpaid professors, then set each of them to 
teach the branch of geology which he knew best. And these professors were no carpet knights; they were knights errant who derived their knowledge, not from books alone, but from their wanderings over hills and dales, in mines and quarries, by ice-polished rocks and water-worn valleys. At its meetings the leaders of the society announced what they had discovered, gave sure and demonstrable proofs of their discoreries, and shored in what direction the geological forces should be directed for the conquest of Nature. The goodly fellowship of the Geological Socicty has always encamped on the ever-advancing frontier of geological knowledge, where the well-surveyed tracks pass out into the bright, alluring realms of the unknown.

The actual founders of the Geological Society were apparently men of less showy intellect than the great Werner, whose teaching had intoxicated many of the most gifted of his enthusiastic pupils. They were men, like Horner and Greenough, who had a practical insight that enabled them to give a permanent help to the progress of science. They had that supreme gift, the power to see things as they are. It would not be fair to claim for them that they were the originators of accurate methods in geology; such methods had been used before their day-by William Smith in England, by Lehman in Germany, and by Desmarest in France. But these men, acting singly, had not been able to save geology from the eighteenth-century spirit of adventurous speculation, nor had they lifted from geology the burden of those quaint theories that made this science the butt of Voltaire's luminous ridicule.

The great achievement of the Geological Society has been this: as a corporate body it has been able to spread its influence very widely; its clear-sighted pursuit of a practical ideal has been adopted in other countries; its resolute rejection of the temptation to wander in dreamland has affected geological students all over the world. In this way has been laid a broad foundation of positive knowledge upon which modern geology has been built.

The fine self-restraint which induced the founders of the Geological Society to restrict its work for awhile to observing the surface of the earth has had its reward. The methods this society was founded to employ have been so widely used that we now have geological maps of a wider area than was known to geographers of a century ago. The general distribution of all the rocks on the earth's surface has been discovered; most settled countries have been surveyed in some detail ; the main outlines of the history of life on the earth have been written and carried back almost as far as palæontologists are likely to go. There are doubtless fossiliferous areas still undiscovered in the 'back blocks' of the world; but, though negative predictions are prorerbially reckless, it seems probable that palæontology will not carry geological history materially farther back. Fossils have been discorered in the pre-Cambrian rocks; the best known is the fauna described by Walcot from Montana; but his Beltina, the oldest wellcharacterised fossil, is still of Palæozoic type. It may be that the poverty of carbonate of lime, which is so characteristic a feature of most Cambrian and præ-Cambrian sediments, indicates that the bulk 
of the contemporary organisms had chitinous shel!s or were softborlied. Palrontology begins with the appearance of hard-bodied organisms; it can only reveal to us the dawn of skeletons, not the dawn of life. We are dependent for knowledge of the climate and geography of Eozoic time to the evidence of the sediments, of which there are great thicknesses beneath the fossiliferous rocks in most parts of the world.:

II. The Geology of the Inner Earth.-Now that this geological surver of the earth is in rapid progress; while the history of life bas been written at least in outline; the chief fossils, minerals, and rocks have been described and generously endowed with names; and the manifold activity of water and air in moulding the surface is duly appreciated. it is not surprising to find that the centre of geological interest is shifting to the deeper regions of the earth's crust and to the problems of applied geology. The secrets of these deeper regions are both of scientific and economic interest. Ther are of scientific importance, for it is now generally recogmised that the main plan of the earth's geography and the essential characters of the successive geological ssstems are the result of internal movements. The relative importance of those restless external agents that we can watch, denuding here and depositing there, has been exaggerated; probably they do little more than soften the outlines due to the silent hearings produced by the colossal energies of the inner earth.

The study of the deeper layers of the crust is of economic interest, for, with keener competition between increasing populations and with the exhaustion of the most easily used resourees of field and mine. there is growing need for the better utilisation of soils and waters, and for the pursuit of deeper deposits of ore.

If a shaft be sunk at any point on the earth's surface a formation of Archran schists and gneisses would probably always be reached; and, working backward, geological methods always fail at last-in primæral, Archean darkness. The Archæan rocks still hide from us the earlier period of the earth's history, including that of all rocks which now lie beneath them. But already there are indications that the myster of the 'berond' is not so impenetrable as it seemed.

1. The Nebular and Meteoritic Hypotheses. - The eighteenth century explained the history of the earth br the nebular hypothesis of Laplace. Geologists respectfully adopted this idea from the astronomers; they accepted it as one of those essential facts of the unirerse with which geological philosophy must harmonise. The resulting theory represented the earth as originally a glowing cloud of incandescent gas, which slowly cooled, until an irregular crust of rock formed around a gaseous or molten core; as the surface grew cooler, the depressions in the crust were filled with water from the condensing rapour, forming oceans which became habitable as the temperature further fell. The whole earth was thought to have had

\footnotetext{
1 Such are the Algonkian sediments represented by the Huronian and Algonkians of America, the Algonkians of Scandinavia, the Karelian of Finland, the Briorarian of Forth-West France, the Heathcotian of Australia, the Transval and Swaziland srstems of South Africa, the Dharwar and Bijawar systems of India, the Itacolumnite series of Brazil, etc.
} 
a long period with a universal tropical climate, under which coral reefs grew where flow our polar seas, and palms flourished on what are now the Arctic shores. Still further cooling had established our climatic zones; and it was predicted that in time the polar cold would creep outward, driring all living beings toward the equator, until at length the whole earth, like the moon, would become lifeless through cold, as it had once been uninhabitable through heat. 'This theory has permanently impressed itself on geological terminology; and its corollaries, secular refrigeration and the contortion of the shrinking crust, once dominated discussions concerning climatic history and the formation of mountain chains. This nebular hypothesis, however, we are now told, is mathematically improbable, or even impossible; and it is only consistent with the facts of geology on the assumption that, in proportion to the age of the world, the whole of geological time is so insignificant that the secular refrigeration during it is quite inappreciable; hence geology can no more confirm or correct the theory than a stockbreeder could refute evolution by failing to breed kangaroos into cows in a single lifetime.

The theory of the gaseous nebula has been probably of more hindrance than help to geologists; its successors, the meteoritic hypothesis of Lockyer and the planetismal theory of Chamberlin, are of far more practical use to us, and they give a history of the world consistent with the actual records of geology. According to Sir Norman Lockyer's meteoritic hypothesis, nebulæ comets and many so-called stars consist of swarms of meteorites which, though normally cold and dark, are heated by repeated collisions, and so become luminous. They may even be rolatilised into glowing meteoric vapour; but in time this heat is dissipated, and the force of gravity condenses a meteoritic swarm into a single globe. Some of the swarms are, says Lockyer, "truly members of the solar system," and some of them travel around the sun in nearly circular orbits, like planets. They may be regarded as infinitesimal planets, and so Chamberlin calls them planetismals.

The planetismal theory is a development of the meteoritic theory, and presents it in an especially attractive guise. It regards meteorites as very sparsely distributed through space, and gravity as powerless to collect them into dense groups. So it assigns the parentage of the solar system to a spiral nebula composed of planetismals, and the planets as formed from knots in the nebula, where many planetismals had been concentrated near the intersections of their orbits. These groups of meteorites, already as solid as a swarm of bees, were then packed closer by the influence of gravity, and the contracting mass was heated by the pressure, even abore the normal melting-point of the material, which was kept rigid by the weight of the overlying layers.

This theory has the recommendation of being consistent with the history of the earth as interpreted by geology. For whereas the nebular hypothesis represents the earth as having been originally intensely hot, and having persistently cooled, yet geological records show that an extensive low-level glaciation occurred in Cambrian times in low Iatitudes in South Australia ${ }^{1}$; indeed, it seems probable

1 As shown by the work of Professor Howchin, of Adelaide. 
that, in spite of mans great local variations, the arerage climate of the whole world has remained fairly constant throughout geological time. Whereas it has often been represented, in accordance with the nebular theory, that volcanic action has steadily waned, owing to the lowering of the earth's internal fires and the constant thickening of its crust, set epochs of intense volcanic action hare recurred throughout the world's history, separated by periods of comparative quiescence. Whereas it has been assumed, as a corollary to the nebular theory, that the force which uplifted mountain chains was the crumpling of the crust owing to the contraction of the internal mass, yet observation reveals that the crust has been corrugated, and fold mountains formed by contraction to an extent far greater than secular cooling can explain.

2. The Materials of the Inner Earth.-This planetismal hypothesis is not only consistent with geological records, but also with the known facts as to the internal composition of the earth and the structure of extra-terrestrial bodies as revealed by meteorites. Meteorites are of two main kinds-the meteoric irons, which consist of nickel iron, and stony meteorites, which are composed of basic minerals. Some of the stony meteorites have been shattered into fault breccias, showing that they are fragments of larger bodies which were subject to internal movements, like those that have formed crush conglomerates in the crust of the earth. Those stony meteorites, therefore, both in composition and structure resemble the rocks in the comparatively shallow fracture zone of the earth's crust. The nickel-iron meteorites, on the other hand, represent the barysphere beneath the crust.

The earth appears to consist of material similar to that of the two types of meteorites; but whether the proportions of the two materials in the earth represent their proportions in other bodies and in meteoric swarms is problematical. There appear to be no satisfactory data for an estimate of the relative abundance in space of the iron and stony meteoric material. Stony meteorites hare been seen to fall far more frequently than iron meteorites; but the largest known meteorites are of the nickel-iron group, although this material, in moist climates, very soon decays. The most reliable indication as to the relative amounts of the stony and nickel-iron meteorites is given by a com. parison of the weight of the two types of material in meteorites of which the fall was seen. According to Mr. Fletcher's list of the meteorites in the British Museum up to 1904, the collection included 319 specimens of which the fall is recorded: of them 305 specimens were stony meteorites of an average weight of $2.63 \mathrm{lbs}$., 9 were iron meteorites of an average weight of $2.31 \mathrm{lbs}$, and 5 were siderolites (or meteorites containing a large proportion of both silicates and nickel-iron) of an average weight of $54 \mathrm{lbs}^{1}{ }^{1}$ Therefore, according to this test, the stony materials would appear to be the more abundant. But if all known meteorites are considered, the iron group far outweighs the other; for the iron meteorites in the British IIuseum

1 The weights are given in pounds avoirdupois. For the calculation I am indebted to $\mathrm{Mr}$. W. R. Wiseman, of the Geological Department of Glasgow iniversity. 
collection weighed 11,873 lbs., as against a total weight of only 865 lbs. of stony meteorites. The available eridence suggests that the stony meteorites fall the more frequently on the earth, but the meteoric irons come in such large masses that they outbalance the showers of the smaller stones.

We might have expected help from another source in examining what lies below the Archran rocks. Cannot the relative proportions of the stony and metallic constituents in the earth help us? Unfortunately, this proportion is as uncertain as that of stony and iron meteoritic material. The best-established fact about the interior of the earth is that its materials are much heavier than those of its crust. The specific gravity of the earth as a whole is about 5.67 ; the specific gravity of the materials of the crust may be taken as about $2 \cdot 5$, while that of the heavier basic rocks is only about $3 \cdot 0$. Hence the earth as a whole weighs about twice as much as it would do if it were built of materials having the same density as those which form the crust.

Two explanations of the greater internal weight of the earth have been given. According to one, the earth is composed throughout of the same material, and the internal mass is only heavier because it is compressed by the weight of the overlying crust. Laplace estimated that the material would gradually increase in density from the surface to the centre, where its specific gravity would be 10.74 , and the calculations of Schlichter show that condensation due to compression may be adequate to account for the greater internal weight.

According to the alternative or segregation theory, the difference in density is explained as due to a difference in composition; the interior of the earth is thought to be hearier owing to the concentration of metals within it. The probability of this metallic interior has been advanced from several lines of evidence; and the assumed metallic mass has received from Posepny the name of the 'barysphere,' or heary sphere. According to this riew the earth is essentially a huge ball of iron, which, like modern projectiles, is hardened with nickel; and it is covered by a stony crust, the materials of which were primarily separated from the metallic mass, like the slag formed on a ball of solidifying iron in a puddling furnace.

It has been objected that the weight of the earth is not great enough for much of it to be composed of metallic iron or of meteoritic material. The specific grarity of iron under the pressure at the earth's surface is about $7 \cdot 7$, and it would be even greater when compressed in the interior. But the barysphere is doubtless impregnated with much stony material that would lessen its weight. An estimate by Farrington (1897) of the arerage specific gravity of the meteorites of which the fall had been recorded is only 3.69 . According to the Rev. E. Hill (1885) the mean specific gravity of all the meteorites in the British Museum was 4.5; and, though Mr. Hill duly considered the effect of compression, he concluded that "the density of the earth is perfectly consistent with its being an aggregation of meteoric materials." Moreover, within the metallic barysphere there may be a core of lighter material; for earthquake 
waves travel more slowly in the central core of the earth than in the intermediate zone, or are even suppressed altogether there; hence the centre of the earth may be occupied by matter less compact than that of the shell around it; and, according to Oldham's calculations, the light central core occupies two-fifths of the diameter of the earth.

The evidence of density alone, therefore, gives no convincing evidence of the nature of the earth's interior; and geologists have been left with no conclusive reason for choosing between the condensation and segregation theories. Radio-activity has, howerer, unexpectedly come to our aid, and has disclosed a further striking resemblance between the internal mass of the earth and the iron meteorites. It has supplied direct evidence about the constituents of the earth at depths which hare hitherto been far beyond the range of observation. Mr. Strutt has shown that radium is probably limited within the earth to the depth of 45 miles, that the deeper-lying material is free from radium, and that this substance is not found in iron meteorites.

The agreement in radio-active properties between the iron meteorites and the interior of the earth is an additional and weighty argument in farour of the view that the earth is largely composed of nickel iron.

3. Physical Conditions and Temperatures. - The physical condition in which the material exists is now of secondary interest. The old controversy as to whether the earth has a molten interior inclosed within a solid shell has lost its importance, because it has become a mere matter of definition of terms. The facts which led geologists to beliere that the interior of the earth is fluid are consistent with those which prove that the earth is more rigid than a globe of steel. For under the immense pressure within the earth the materials can transmit vibrations and resist compression like a solid; but they can change their shape as easily as a fluid. They are fluid just as lead is when it is forced to flow from a hydraulic press. Not only are geologists now justified in their belief that the deeper layers of the earth's crust are in a state of fluxion, but, according to drrhenius (1900), the earth is solid only to the depth of 25 miles, below which is a liquid zone extending to the depth of 190 miles; and below that level, he tells us, "the temperature must, without doubt, exceed the critical temperature of all known substances, and at this depth the liquid magma passes gradually to a gaseous magma." This distinguished physicist gives a description of the earth's interior which reminds us of the views of the early geologists. Arrhenius's theory rests, howerer, on the existence within the earth of exalted temperatures; and this assumption a geologist may now hesitate to accept with less risk of getting into disgrace than he would have run a few jears ago. It is improbable that the rapid increase of heat with depth which is observed near the surface should continue below the lithosphere; for, if the earth consists in the main of iron, even although it be arranged as a mesh containing silicates in the interspaces, the heat conductivity might be sufficient to keep the whole metallic sphere at a nearly equal temperature. Here, again, Mr. Strutt's work on radio-activity is in full agreement with the requirements of geologists, for he estimates that below a crust $4 j$ miles thick the earth has a uniform 
temperature of only $1,500^{\circ} \mathrm{C}$. Whether the further conclusion that this heat is due to the action of the radium in the crust be established or not, it is gratifying to hear a physicist arguing in favour of a moderate and uniform internal temperature.

All that the actual obserrations prove and that geological theories require is that the material within the earth be intensely hot, and that it lie under such orerwhelming pressure that it would as readily change its form and as quickly fill up an accessible carity as any liquid rould do. Whether such a condition is to be described as solid, liquid, or gaseous is of little concern to geologists.

III. The Depp-seated Control over the Earth's Surface.-The modern view of the structure of the earth adds greatly to the interest of its study, for it recognises the world as an individual entity of which both the geological structure and the history have to be considered as a whole. Once the earth was regarded as a mere lifeless, inert mass which has been spun by the force of gravity, that hurls it on its course into the shape of a simple oblate spheroid. Corresponding with this astronomical teaching as to the shape of the world was the geological doctrine that all its topography is the work of local gengraptical agents, whose control over the surface of the earth is as absolute as that of the sculptor's chisel over a block of marble.

Both these conceptions are now only of historic interest. The irregular indiridual shape of the earth is expressed by its description as a geoid. The processes which have produced its rarying shape have also controlled its geological history and evolution, for they cause disturbances of the crust, which affect the whole earth simultaneously; and so the geographical agents are given similar work and powtrs at the same time in different places.

Hence there is a remarkable worldwide uniformity in the general characters of the sedimentary deposits of each of the geological srstems. The last præ-Cambrian systom includes thick masses of felspathic sandstones alike in the Torridonian of Scotland, the sparagmite of Scandinavia, the Keweenawan Sandstones of the United States, and perhaps also the quartzites of the Rand. The Cambrian has its greywackes and coarse slates and its numerous phosphatic limestones; the Ordovician its prevalent shales and slates; the Silurian its episodal limestones and shales. The Devonian has its ride areas of Old lied Sandstones as a continental type, while its marine representatives show the prevalence of coarse grits and sandstones in the lower series, of limestones and slates in the middle series, and the recurrence of sandstones in the upper series; and this sequence occurs alike in North-Western Enrope, in America, and Australia. The Carboniferous contains the first regional beds of thick limestone and the first important Coal-measures. The Trias is as characterised br rocks indicating arid continental conditions in America and Australia and South Africa, as Professor Watts has shown then prerailed in the neighbourhood of Leicester. In the Mesozoic era we owe to Suess the demonstration of the worldwide influence of those marine encroachments or 'transgressions' whereby the great continents of the Trias were gradually submerged by the rising sea.

Speaking generally, there is a remarkable lithological resemblance DECADE V.-VOL. IV.-No. IX. 
between contemporary formations in all parts of the world. This fact had been often remarked, but was usually dismissed as due to a number of local isolated coincidences of no special significance. But the coincidences are too numerous and too striking to be thus lightly dismissed. They are among the indications that the main earthchanges have been due to world-wide causes, which led to the predominance of the same types of sedimentary rocks during the same period in many regions of the world.

The conditions that govern the geological evolution and general geography of the earth are probably due to the interaction between the earth's crust and the contracting interior; they may take place as slow changes in the form of the earth, causing the slow rising or lowering of the sea surface, or the slow uplift or depression of regions of the earth's crust; or they may give rise to periods of riolent volcanic action in many parts of the earth, between which may be long periods of quiescence. The geographical effects of changes in the earth's quivering mass affect distant regions at the same time. Therefore the landmarks of physical geology will probably be found to give more precise evidence as to geological synchronism than those of palæontology, on which we have hitherto had to rely.

(To be concluded in our next Number.)

II. - British Association for the Advancement of Science. List of Titues of Papers nead in Section C, Geology, Augtst 1 sT To $7 \mathrm{TH}, 1907$.

Presidential Address by Professor J. W. Gregory, F.R.S. (p. 409.) C. Fox-Strangways. - Geology of Country round Leicester. (p. 420.) Professor W. W. Watts, F.R.S.--The Geology of Charnwood Forest. Dr. F. W. Bennett.-The Felsitic Agglomerate of Charnwood Forest. Dr. B. Stracey.-The North-West District of Charnwood Forest. (p. 420.)

A. $R$. Horwood. - The Palæontology of the North Derbyshire Coalfield. (p. 421.)

H. T. Ferrar.-Some Desert Features.

Trias Report-Investigation of the Fauna and Flora of the Trias of the British Isles.

(a) Dr. Smith Woodward.-On Labyrinthodon leptognathus, Owen.

(b) H. C. Beasley.-Footprints from the Trias.

(c) J. Lomas.-Footprint Slab in Museum of Unirersity of Liverpool.

(d) A. R. Horwood.-The Flora and Fauna of the Trias.

(e) L. J. Wills.-Fossils of the Lower Keuper of Bromsgrove.

Professor H. G. Seeley, F.R.S.-On the Structure of the Mandible of a South African Labyrinthodont.

T. O. Bosworth.-The Origin of the Upper Keuper.

$W$. Keay \& M. Gimson.-The Relation of the Keuper Marl to the Pre-Cambrian Rocks at Bardon Hill.

H. Bolton $\&$ C. J. Waterfall.-On the Occurrence of Boulders of Strontia in the Upper Triassic Marls of Abbott Leigh, near Bristol. 
Dr. Cullis.-On a peculiarity in the Mineralogical Constitution of the Keuper Marl.

Discussion on "Iron Ore Supplies," to be opened by Bennett Brough and Professor Sjögren.

Professor J. Joly.-The Distribution of Radium in the Rocks of the Simplon Tunnel.

W. G. Fearnsides. - On Pisolitic Iron-ores from North Wales. (p. 422.)

F. Raw.-The Trilobite Fauna of the Shineton Shales.

F. Raw.-Development of Olenus Salteri.

Dr. A. Vaughan.-Report on Carboniferous Faunas.

W. G. Fearnsides.-Report on Place-Names.

Professor S. H. Reynolds.-Report on Pre-Devonian Rocks of the Mendips.

Professor J. Milne, F.R.S.-Destructive Earthquakes.

Professor Frech.-Mountain Building and Seismology.

J. W. Stather.-Report on Kirmington Deposits.

J. W. Stather $\$$. Sheppard.-Gravels of Holderness.

$J$. Lomas. - On a Marine Peat at Liverpool.

A. R. Horwoood.-A Section of Middle Lias at Bellesdon.

Rev. S. S. Dornan.-Ancient Volcanoes of Basutoland.

E. Greenly.-Report on Anglesey Rocks.

Dr. Wheelton Hind.-Report on Carboniferous Zones.

Report on Erratic Blocks.

Titles of Papers read in other Sections bearing upon Geology :-

\section{Section A.-General Phystcs.}

A. O. Rankine.-On a theoretical Method of attempting to detect relative Motion between the Ether and the Earth.

Report of the Committee on Seismological Observations.

Professor E. Rutherford, F.R.S.-On the Production and Origin of Radium.

Professor E. Rutherford, F.R.S., \& Dr. J. E. Petavel, F.R.S.-The Effect of High Temperature on the Activity of the Products of Radium.

T. J. J. See.-Results of Recent Researches on the Physics of the Earth.

\section{Section B.-Chemistry.}

Professor Phillips Bedson.-Explosions in Coal-mines: Experiments illustrative of the Inflammability of Mixtures of Coal Dust and Air.

$$
\text { Section D.-Zoologr. }
$$

Report of the Committee on the Index Animalium.

$$
\text { Section E.-Geography. }
$$

Professor J. W. Spencer.-The Recession of Niagara.

H. T. Ferrar.-Physical Geography of the Etbai Desert of Egypt. Dr. Vaughan Cornish. - The Jamaica Earthquake. 


\section{Section H.-Anthropology.}

Report of the Committee to conduct Explorations with the object of ascertaining the Age of Stone Circles.

Report of the Committee to Investigate the Lake Village of (ixlastonbury.

\section{Section K.-Botayy.}

Professor F. W. Oliver, F.R.S.-On the Structure and Affinities of Physostoma elegans (Williamson), a Pteridospermous seed from the Coal-measures.

D. M. S. Watson.-The Cone of Bothrodendron mundum.

Papers read in Section C (Geology), British Associatron, Letcester, August, 1907.

III.-Notes on the Geology of Leicestershire. By C. FoxSirangwaYs, F.G.S.

THE chief features of the district were briefly described, with 1 a general account of the formations that are exposed throughout the county. These are comprised in the following main dirisions in descending order: Recent and Pleistocene, Jurassic, Triassic, Permian, Carboniferous, and Pre-Cambrian. The first of these includes the river deposits and glacial beds. The Jurassic rocks comprise only the two lower subdivisions of the Lincolnshire Limestone and the Northampton Sand, together with the Lias. The Trias occurs in the usual two divisions of Keuper and Bunter. 'The Permian consists of breccia and marls, the age of which is to some extent doubtful. The Carboniferous is well exemplified in the three subdivisions of Coal-measures, Millstone Grit, and Limestone; but the lower beds are not of the importance they attain elsewhere. The Pre-Cambrian rocks are divisible into three main groups, as shown by Professor W. W. Watts-the Brand Series, the Maplewell Series, and the Blackbrook Series. Special attention was directed to the more important exposures of these rocks, and to the principal points in the local geology that are obscure and require further elucidation.

\section{IV.-The North-West District of Charnwood Forest. By Bernard Stracey, M.B., F.G.S.}

\footnotetext{
$A^{\mathrm{s}}$ $S$ the north-west of Charnwood Forest is approached the rocks become more altered, the faulting is greater, and igneous rocks are met with. The rent which ejected the rocks of the forest seems to lie in this direction.

Bardon Hill.-The centre and part of the north flank are composed of rock resembling an igneous rock; evidence is given to show that this rock differs from the agglomerates found in the north-west area, with which it has hitherto been correlater. Certain rocks between the Bardon rock and the Peldar porphyroid seem to bear some relation. to the felsitic agglomerate.
} 
Birchill Plantation.-Recent research in this exposure has shown the identity of the rock with that found at Bardon Hill. On the north side rocks belonging to the Felsitic Agglomerate Series have also been found.

Peldar Tor.-The porphyroid exposed in the large quarries contains inclusions of other rocks, which have been generally considered as segregation masses. An undoubted dyke in the middle of Peldar Tor has been exposed.

Ratchet Hill.-An exposure in this hill shows the presence of rocks on the felsitic agglomerate horizon. At the north-west end a porphyroid occurs which seems to be identical with the porphyroid at Cadman Wood.

Swannymote and Trilobate.-Rock belonging to the Felsitic Agglomerate Series runs between these two places; it has been much altered, and has not hitherto been recognised as belonging to the felsitic agglomerate.

V.-A Contribution to the Paldentology of the North Derbyshire and Notrs Coalpield, or the Southern Part of the North Midusnd Coalfield. By A. R. Honwood, Sub-Curator, Leicester Corporation Museum.

SUMMARY was given of the extent and position of the North ¿ Midland Coalfield. Allusion was then made to the previous work connected with the palæontology of the district. This was very limited, and the correlation of the Top Hard Coal with the Main Coal of Leicestershire, and of the Black Shale with the Arley Mine of Lancashire, had not been founded on fossil evidence.

Recently the resurvey of the district by the Geological Survey and some important borings had added much to our knowledge of the fossil flora and fauna met with.

As a result of these investigations, and by the aid of a summary of all the previously recorded organic remains from this area, the author was able to arrive at the following conclusions:-

1. That the flura of the 'I'op Hard Coal, as afforded by specimens from Pleasley, indicates that it is of the same age as that of the Main Coal of Leicestershire and South Derbyshire (in both the Western or Moira and Eustern or Cole Orton Districts), i.e. of Middle Coalmeasure age, occupsing a position rather more than midway in that division of the Coal-measures.

2. The fauna of the horizon at Mansfield, Notts, 630 feet above the Top Hard Coal, indicates, as pointed out by Mr. Waleot Gibson, a horizon equivalent to the Gin Mine or 'I'wist Coal of the North Staffordshire Coalfield, i.e. near the top of the Middle Coal-measures and commencement of the Transition series, or Black Band group, which would occupy a position slightly higher. Eastward and above this horizon the whole of the Upper Coal-measures are represented, though feebly dereloped.

3. The Coal-measures of North Derbyshire are, as a whole, entirely confined to the limits of the Grey or chief coal-bearing series (Lower 
and Middle Coal-measures), like the Leicestershire and South Derbyshire Coalfield, of which it is a continuation; and none of the Red series (or Transition series and Upper Coal-measures) of the North Staffordshire type are met with in this area west of a line somewhat east of the Nottinghamshire and Derbyshire County boundary between Bolsover and Stanton, though this line probably curves westward in the north, just south of Rotherham, and eastwards, south and southeast of Nottingham.

A summary of the fossil flora and fauna of North Derbyshire and Nottinghamshire, as at present known, was given, with the horizon and locality of the specimens cited. This, though preliminary, was in extension of the work already accomplished in the Leicestershire and South Derbyshire Coalfield, shortly to be published, and in other fields, and supplementary to the work of Ward, Hind, and Stobbs in the North Staffordshire Coalfield on the mollusca and fish fauna of that area, and of Kidston on the fossil floras of Yorkshire and North and South Staffordshire.

\section{VI.-On the Pisolitic Iron-ores of Wales. By W. G. Fearnsides,} M.A., F.G.S.

ITHE first part of the paper discusses the occurrence of the wellknown iron-ores of Caernarvon and Merioneth, and shows that though they have been taken by various writers as marking a wellconstituted subdivision of the Tremadoc slates they are really of the nature of fissure phenomena, and may occur at almost any horizon.

The various worked exposures seem always to agree in the following particulars :-

(1) They are associated with the occurrence of large hypabyssal or minor plutonic intrusions of sill-like habit, and occur: among stratified rocks along the limit of the sill's metamorphic area.

(2) They occur in more or less lenticular masses, of no considerable lateral extent, often heaped together and separated by crushed shale partings in a way which may suggest bedding, but often thinning out yet maintaining a linear arrangement across considerable tracts of country.

(3) Considerable lenticles of ore are always associated with darkblue or black shales or slates, which nearer to the igneous intrusion have become bleached and spotted through the influence of that intrusion. On the side of the ore body nearest the intrusion the country rock is usually little disturbed, and lies evenly; but on the side remote from the intrusion the country rock is crossed and recrossed by planes of slickenslide, and is often intensely nodular.

The more important stratigraphical horizons which have developed pisolitic ore bodies in the North Welsh district are:-

(1) Lower Lingula flags. Bettws Garmon. Black shales which underlie the grey flaggy sandstones with Lingulella beds.

(2) Upper Lingula flags. North flank of Aron Mawdly. Adjoining shales contain Peltura scarabaoides.

(3) Upper Arenig Shales. Moelwyn Bach; Milltirgerig, Arenig; below Llyn $y$ gader, Cader Iris. Country rock contains abundant Didymograptus bifidus. 
(4) Llandeilo Shales (Glenkiln facies). Tiddyn Diewm, Tremadoc. Country rock contains graptolites of the Didymograptus Ilurchisoni and Conograptus gracilis zones.

The workings of Pistyll near the Rivals seem to belong to a horizon higher thun any of these, and may be among the Hartfell (Bala) shales.

The second portion of the paper deals with the probable petrological and chemical history of the iron-ores.

Eridence is brought forward to show that the ore bodies have been only profitable near the present surface, and when smelted with wood charcoal. They are always very rich in pyrites or marcassite, which in certain specimens from the deep termination of an adit makes up about 60 or 70 per cent. of the rock. The ores are always impure, and contain much crushed, streaky or fibrous shale between the pisoles. Where freshest the pisoles of sulphides show only radial arrangement of the constituent fibres, but there may also be concentric structures which are masked by the opacity of the mineral. The radial fibres of sulphidic minerals usually grow out from or around quartz grains or other clastic fragments of country rock or of earlier formed pisolite grains. During oxidation the sulphidic material is attacked in stages from the outside and passes by obscure processes, first to a colourless and soluble green pleochroic mineral, and afterwards to fibrous limonite and compact magnetite, and it is the differential development of the rarious stages which gives the resultant pisoles of the profitable ore their well-marked concentric structure.

That all the pisolitic grains contained in the iron-ores of North Wales have been formed as radial growths of iron sulphides is not yet clear, but the method of their geological occurrence will well accord with the hrpothesis that they may be the concentration products of the non-carbonaceons colouring matters driven off by the heat of the intrusion from the black shales consilered above.

An occurrence of perfectly fresh masses of radial pyrites at the limit of a 12-20 feet metamorphic aureole in the Llandeilo shale of Harper Quarry, Builth, shows that such concentration can occur on a small scale, while the finding of considerable lenticles of iron-ore which are wholly pyrites, and have been concentrated during the turning of coal into anthracite in the Emlyn Mine, Llandeby, near Llandeilo, would seem to show that recrystallized pyrites does tend to take on a pisolitic habit.

\section{REVIEW}

\section{Acstratian Grology.}

Staxford's Compexpica of Geography, etc. New issue, 1907.

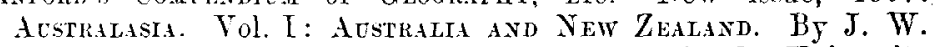
GrREcionx, D.Sc., F.R.S., Professor of Geology in the University of (Glasgow. (London: Edward Stanford.)

' 'HE whole of this volume abounds with geographical and geological 1 references, as might be expected from the author, and is also exceedingly well illustrated with maps, etc. Chapter ir, "The 